\title{
Analysis of Pre-Service Music Teachers' Ability to Accompany School Songs on Piano
}

\section{Research Article}

\section{Omer Bilgehan SONSEL ${ }^{1}$, Cagla SERIN OZPARLAK ${ }^{2}$}

${ }^{1}$ Gazi University, Faculty of Education, Department of Music Education, ORCID: 0000-0001-5814-4363

${ }_{2}$ Gazi University, Faculty of Education, Department of Music Education, ORCID: 0000-0001-9951-2994

To cite this article: Sonsel, O. B., \& Ozparlak, C. S. (2020). Analysis of Pre-Service Music Teachers' Ability to Accompany School Songs on Piano, International Online Journal of Educational Sciences, 12(3), 110-125.

\begin{tabular}{l} 
ARTICLE INF \\
\hline Article History: \\
Received: 16.12 .2019 \\
Available online: \\
29.06.2020
\end{tabular}

29.06.2020

\begin{abstract}
Use of a piano accompaniment by music teachers in song teaching allows students to improve their rhythmic hearing, hear the polyphony, and comprehend the discipline of collective music. A music teacher learns the concept of piano accompaniment mainly in piano accompaniment course existing in the curriculum of music teaching bachelor program, as well as several other courses focusing on educational music. Being a descriptive study, purpose of this research is to analyze the ability of preservice music teachers in terms of piano accompaniment. The study was conducted with 85 preservice teachers, who are 3rd and 4th year undergraduate students at Gazi University Gazi Faculty of Education Department of Music Education, and voluntarily participated in the study. Having been conducted in 2019-2020 Academic Year Fall Semester, a "school song accompaniment form" was used in the study, which was prepared by the researchers and took its final form with the opinions of field specialists. The form was applied to pre-service teachers in order to evaluate their knowledge on tonality/maqam, measure based functioning, use of an accompaniment model, and fluency in playing, based on one major, one minor, and one huseyni school song. Application process was recorded on video and submitted to 3 field specialist which was then followed by the calculation of the arithmetic mean of their evaluations, leading us to the findings of the research. The study concluded that the level of participants' knowledge ontonality/maqam is good; whereas it is intermediate in terms of measure based functioning, and low when it comes to the knowledge ofusing an accompaniment model and fluency in playing. These data were tabulated and interpreted under related headings. Study results indicate the insufficient level of accompaniment practice in current music education bachelor programs. It is believed that future studies involving more accompaniment applications and contents will reach higher results.
\end{abstract}

(C) 2020 IOJES. All rights reserved

Keywords:

Accompaniment, Piano accompaniment, School song, Educational Music. 


\section{Introduction}

Dimensions of music education are composed of teaching basic music knowledge, singing, playing an instrument, musical creativity, and music appreciation. In all these dimensions, the main element is the songs. Playing an instrument and musical creativity are the outcomes of a process. Students get to achieve these dimensions with the help of an educational process and their knowledge. Singing, on the other hand, is only possible when students use their voice and rhythmic hearing. Therefore, vocal training is the main dimension among all the others. Songs that are written in accordance with the ages of children - ranging from preschool period until the end of adolescence - are the main tools used by music teachers in order to teach and endear music to these children and teenagers, and have them integrate it to their lives (Piji, 2018, p.6). Besides, its contribution to collective singing, vocal training within general music education also enhances the social and emotional development of the individual, which is a natural outcome of this contribution (Bilen, 1995, p.14). Turkish children songs and educational music repertoire is especially used during main educational process where general music education is also provided (Türkmen, 2010, p.185). Starting from preschool music education, music teachers teach school songs to students until the last stage of general music education, and perform activities with these songs. Singing activities help students improve their hearing and note reading skills, learn and practice basic music knowledge (Özmenteş, 2005, p.95). According to Bilgin (2004, p.286), it is possible to train the voices and hearing skills of students, improve their ability to make music, and enable their musical development, by means of teaching school songs.

Being the building block of general music education, school songs serve for different purposes in each stage of education. While preschool focuses on ensuring individual and environmental awareness or realizing social facts and behaviors such as traffic, our bodies, and seasons; primary education aims to have students acquire certain musical behaviors (Çevik and Güven, 2011, p.88). Such importance of school songs in every stage of musical education requires the content of music teaching bachelor program to be rich and qualified, as well. Courses available in music education bachelor programs consist of three main qualities. These are;

- Courses for professional knowledge

- Courses for general knowledge

- Courses for field knowledge

Courses focusing on professional knowledge enable pre-service teachers to be equipped with the necessary pedagogical knowledge, and improve their approach towards the profession of teaching. These courses are not directly related to music, but rather focuses on the general knowledge and skills of teaching. Courses for general knowledge are the ones that all bachelor degree students at any faculty/department must take; such as Turkish language, foreign language, and history. Courses for field knowledge, on the other hand, is a complement of courses where students are equipped with the knowledge and skills related to music teaching. Purpose of these courses are to provide the professional efficacy of pre-service teachers. These three types of courses are all required for a bachelor degree student so that $\mathrm{s} / \mathrm{he}$ can graduate as a qualified teacher. A qualified music teacher must both comprehend the content of these three course package and be able to interconnect these courses. A teacher is considered qualified when all these courses are achieved.

Akbulut's (2006, p.3) opinions on teacher efficacies are also in parallel with this study. According to Akbulut, non-existence or lack of a professional quality in music teaching, in a way, means the deficiency of a significant dimension in professional quality of music teaching. An effective music teacher must own all these dimensions that make up professional qualities. 


\section{Accompaniment and Piano as an Accompanying Instrument}

Accompaniment is an important aspect of song teaching. Bilgin (1998, p.24) describes accompaniment as "accompanying part or parts whose purpose is to support the main melody line or vocal part; to complement the substructure of the song and serve as a basis; or to enhance the main melody line or vocal party and therefore bring it to the fore with the help of harmony or additional melodic lines". Say (2005, p.186), on the other hand, stated that "part or parties that promote the main sound in a piece, are the musical togetherness which reveal the harmonic quality of a piece in vocal or instrumental music and bring a content and depth to it. Teaching songs with the accompaniment of an instrument both enables the students to sing the song on a right melody easier, and improve their hearing skills (Küçükayvaz, 2019, p.68). The accompaniment courses which are available in music teaching bachelor programs practically use the piano. The purpose of the course is to allow the students to acquire certain skills such as playing the accompanying parts of school songs, perform improvised accompaniments, write accompaniments for school songs, and play their own accompanying party. In these courses, as well as being able to play the piano very well, pre-service music teachers are also expected to combine the behaviors they acquired in the fields of piano, harmony, counterpoint, and music theories; and therefore gain a more functional quality (Sönmezöz, 2006a, p.316).

With its ability to create harmony and quality of tonal togetherness with other instruments, piano is accepted as the leading accompanying instrument to be used in every field where music is produced, from the smallest music groups to big orchestras (Pala, Zahal and Gürpınar, 2016, p.12).

With its polyphonic structure, piano has an outstanding place among all other instruments, and provide convenience for musicians in many fields, especially in composing. Its polyphonic structure enables the piano to act as an orchestra by itself, as well as the ability to accompany other instruments (Gün and Öztürk, 2017, p.122). Playing an instrument solo or as the accompanying instrument is totally different from each other. A qualified musician may face difficulties while performing a very simple music on another instrument, unless $\mathrm{s} /$ he is trained or experienced in that field. Lavignac (1939, p.69) distinguishes the difference between playing solo and accompaniment by saying "Every musician must play the instrument with others or play in an orchestra, so that s/he can master in that instrument. The point here is totally different from making music alone. Some musicians may perfectly play violin, flute, or obua solo; whereas they may feel like a total stranger while performing music collectively".

According to Tecimer (2005, p.150), while teaching piano as the accompanying instrument, the aim must be to have pre-service teachers acquire certain skills, such as the ability to accompany a given melody, sighread, transpose, perform polyphony, analyze, improvise, play together, and perform the parts of choir orchestra pieces on the piano. A music teacher who gain these functional skills will be able to use the piano much more efficiently while teaching in a class and accompany school songs or instrument groups. A teacher who accompany school songs with piano, together with the students, will also enable the students to listen to the piano and gain the sense of polyphony, as well as keeping them in the same tempo and tone (Zuckmayer, Cangal, and Atalay, 1976, p.11).

The polyphonic structure of the piano makes the teaching process of school songs more entertaining and efficient, and allow the teacher to achieve a better teaching in a shorter time. Therefore, piano is more advantageous when compared to other instruments. Another reason why piano is the main accompanying instrument is its ability to play an active role in the teaching of all songs, thanks to its wide octave range. In terms of being sonorous and its dominance over the teaching of a song make piano the ideal instrument for the class (Sönmezöz, 2006b, p.5). Besides reinforcing the sense of tempo, clear unison, intended feeling, thought, and theme; use of piano accompaniment in song teaching also provides the feeling of satisfaction in song practices from different types (Özalp and Özdemir, 2015, p.49). 
Due to being expensive and difficult to carry or accord them, acoustic pianos were hardly used in music courses in the past. However, with the widespread of electronic pianos especially after 2000s, such difficulties disappeared and it became a more affordable instrument. In other words, it turned into a more usable and advantageous instrument for music courses.

\section{Efficacy of Music Teachers in terms of the Ability to Play Piano Accompaniment}

It goes without saying that the ability to compose and accompany in educational music is the most important dimension of music teaching, which is field specific and focuses on creativity (Tunç and Albuz, 2010, p.48). The accompaniment performed by the music teacher to support song teaching in primary school music lessons, will color up the emotional and imaginary world of students and provide several values in terms of polyphony (Şaktanlı and Özelma, 2014, p.44). School songs may vary in terms of melody, harmony, form, and other musical elements. A music teacher who has the knowledge and skills acquired during the harmony, counterpoint, accompaniment, and piano education provided at divisions of music teaching, is expected to be able to analyze every piece in terms of melody, form, and musical elements (Bilgin, 1998, p.33). Students may get accustomed to polyphony by means of teaching the songs with the help of accompaniment. At this point, piano is to be used primarily as an accompanying instrument in education (Batıbay and Aydınoğlu, 2006, p.3).

Accompaniment of the songs in music courses entirely depends on the knowledge and skills of the music teacher in that field. Therefore, pre-service music teachers must improve their accompaniment skills throughout their education so that they can be efficient in class (Piji, 2007, p.114). Accompanying a song is in close relation with the ability of musical hearing, musical analysis, harmony-counterpoint, knowledge on how to create accompaniment, and adequate analysis and consumption of appropriate samples created for this purpose (Babacan, 2009, p.10). Besides being able to play a given accompaniment, a music teacher is also supposed to have a command of subjects; such as harmony-counterpoint and how to write accompaniment, so that s/he can accompany a monophonic school song. Harmony is defined as the body of rules that covers connections and motions composed of simultaneous movement of the chords of three or more notes (Gün and Demirtaş, 2016, p.1390). Harmony and counterpoint activities available in the program allow the pre-service music teachers to feel and reveal the hidden polyphony in a monophonic melody, and put it into practice (Sevgi, 2005, p.201). Training and teaching correct accompaniment techniques to an undergraduate student, who has comprehensive knowledge on harmony and the minimum technique in terms of playing piano, will enhance the competency of pre-service teachers. Therefore, use of piano accompaniment at primary music lessons is of great importance in terms of improving the efficiency and quality of music education (Demirtaş, 2011, p.10-11). However, in institutions training music teachers; accompaniment and performing accompanied school songs, which is one of the methods required in educational music and its teaching, are ignored while performing and/or attempting to perform pieces with a huge artistic function. These methods are essential for the fields of professional music and education (Dağdeviren, 2006, p.311). The main purpose of piano education must be the acquisition of accompaniment skills where pre-service teachers become able to easily and practically accompany school songs on piano or another electronic instrument with the similar sound and touch, without the necessity of long preparations. For this, music teachers must be theoretically competent in basic functional chords in harmony; such as I (Tonik), IV (Subdominant), and V (Dominant), and their subcategories. They must also be able to react quickly in all tonalities - both major, minor, and maqami - in terms of hearing and playing them on the piano, which can be achieved throughout their undergraduate educations (Sökmen, 2018, p.27). In tonal harmony, "I-IV-V-I" is accepted as a perfect cadence and used in the accompaniment of many school songs. Similarly, the "I-VII-III-I" cadence in maqami harmony can also be used in the accompaniment of several maqami school songs. For this reason, a music teacher must be able to accompany by using these functions. 
However, despite the importance of performing a school song with accompaniment, there are only few songs in the repertoire written as such. Especially, most of the songs in music lesson books were written without an accompaniment (Piji, 2014, 199). At this point, it is the responsibility of music teachers to accompany these songs and bring a polyphony to them. In order to accompany a school song without a ready accompaniment, a music teacher must be able to analyze the rhythmic-harmonic relations between the melody and accompanying party; combine the chords in the accompanying party correctly; search and find the accompanying figures that are appropriate for the rhythmic structure and style of the melody; and make sure that the accompanying party has an organic and aesthetic integrity (Bilgin and Şaktanll, 2007, p.132).

Based on the fact that the ability of music teachers to accompany school songs on piano is of great significance, the problem statement of the study was identified as "What is the status of pre-service music teachers' ability in terms of accompanying school songs on piano?". In the light of this main problem statement, the following sub-problems were sought for answers:

1. How is the status of pre-service music teachers in terms of the ability to accompany the major song "Sağlık" (Health)?

2. How is the status of pre-service music teachers in terms of the ability to accompany the minor song "Cici Köpeğim" (My Sweet Dog)?

3. How is the status of pre-service music teachers in terms of the ability to accompany the maqami song "Gel Bize Katıl Bize" (Come And Join Us)?

\section{Method}

This part of the study focuses on the topics of research model, research process, study group, and preparation and application of data collecting tools.

\section{Research Model}

The study is conducted in cross-sectional survey design, which is a type of descriptive research in quantitative research models used for the identification of an existing situation.

Purpose of descriptive studies is to research a case as it is, and identify an existing situation. Survey researches are studies that are widely used in social sciences. These studies are conducted on large groups, where opinions and attitudes of people towards a phenomenon and case are recorded, as well as the attempt to describe these phenomena and cases. Being a subtype of descriptive survey, cross-sectional survey design refers to data collecting researches, where certain groups are identified in a population for cases that affect large groups, when the whole group - in other words, the whole population - cannot be reached (Karakaya, 2012, p.59-61). 


\section{Research Process}

Reviewing School Songs

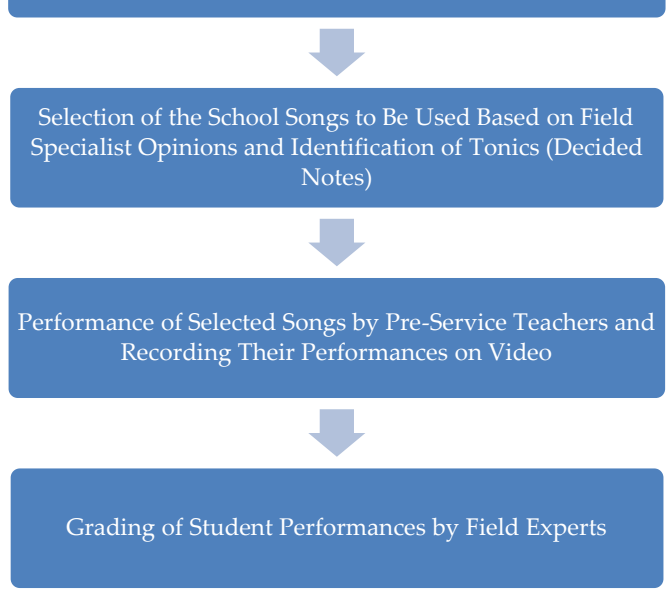

\section{Study Group}

1. Study group of the research is composed of $373^{\text {rd }}$ year and $484^{\text {th }}$ year undergraduate students studying at Gazi University Gazi Faculty of Education Department of Fine Arts Teaching Division of Music Education, in 2019-2020 Academic Year Fall Semester. The following points were taken into consideration while determining the levels of students to be included in the study.

There are certain undergraduate level courses to be fulfilled by pre-service music teachers, who are expected to be able to accompany school songs on piano and create accompaniment. According to 2014's curriculum, these courses are:

- School instruments (Guitar, baglama, and block flute) $-1^{\text {st }}, 2^{\text {nd }}$, and $3^{\text {rd }}$ semesters;

- Music theory and hearing education (Turkish and Western) $-1^{\text {st }}, 2^{\text {nd }}, 3^{\text {rd }}, 4^{\text {th }}, 5^{\text {th }}$, and $6^{\text {th }}$ semesters;

- Individual piano - Compulsory in the $1^{\text {st }}, 2^{\text {nd }}, 3^{\text {rd }}$, and $4^{\text {th }}$ semester and elective in the $5^{\text {th }}, 6^{\text {th }}, 7^{\text {th }}$, and $8^{\text {th }}$ semesters;

- Harmony, counterpoint, accompaniment - Compulsory in the $3^{\text {rd }}$ and $4^{\text {th }}$ semesters and elective in the $5^{\text {th }}, 6^{\text {th }}$, and $7^{\text {th }}$ semesters;

- Educational music repertoire $-4^{\text {th }}$ semester;

- Playing accompaniment with piano $-5^{\text {th }}$ semester.

Based on the semesters of courses, a pre-service music teacher, who has completed the compulsory courses in the curriculum, is expected to be able to accompany a tonal school song on the piano, or create one. At this point, a pre-service teacher who has completed the first four semesters is expected to be sufficient in terms of accompaniment. Upon consideration of the course semesters, $3^{\text {rd }}$ and $4^{\text {th }}$ year students were included in the study group to accompany tonal school songs.

2. Courses to be completed by pre-service music teachers, who are expected to be able to accompany maqami school songs on piano or compose one, are common with those required to be able to compose accompaniment for tonal school songs. In addition to these, the "Polyphonization of Turkish Music" course in the $6^{\text {th }}$ semester is a fundamental course to compose accompaniment for a maqami song. Based on the course semester, $3^{\text {rd }}$ year student were excluded from the study since they have not taken the course yet. Instead, $4^{\text {th }}$ year students were involved in order to accompany the identified maqami school song.

3. 


\section{Preparation and Application of the Data Collecting Tool}

A "school song accompaniment form" was used as the data collecting tool in the study, the purpose of which is to analyze pre-service music teachers' ability to accompany school songs on piano. 2 professors and 1 assistant professor, who are specialists in the fields of composing educational music and accompaniment, were consulted for their opinions while designing the form. A total of three songs were included in the form; two of them being tonal (1 major, 1 minor) and one in huseyni. The reason why huseyni maqam was chosen is that it is the first maqam to be taught in "Polyphonization of Turkish Music" and most of the school songs that are written in maqami form is in huseyni. Points such as having clear harmonic functions, easy access to musical sentences, not including wide vocal ranges, and suitability for accompaniment with perfect cadence chords, were considered while determining the school songs to be included in the form. In line with opinions of field specialists, tonal song tonics were identified as D, and A for songs in huseyni form. Based on the opinions, the songs were included in the form as:

\section{- The song 'Sağlık' (Health) - Czech Melody, Adapted by: ErdoğanOkyay}

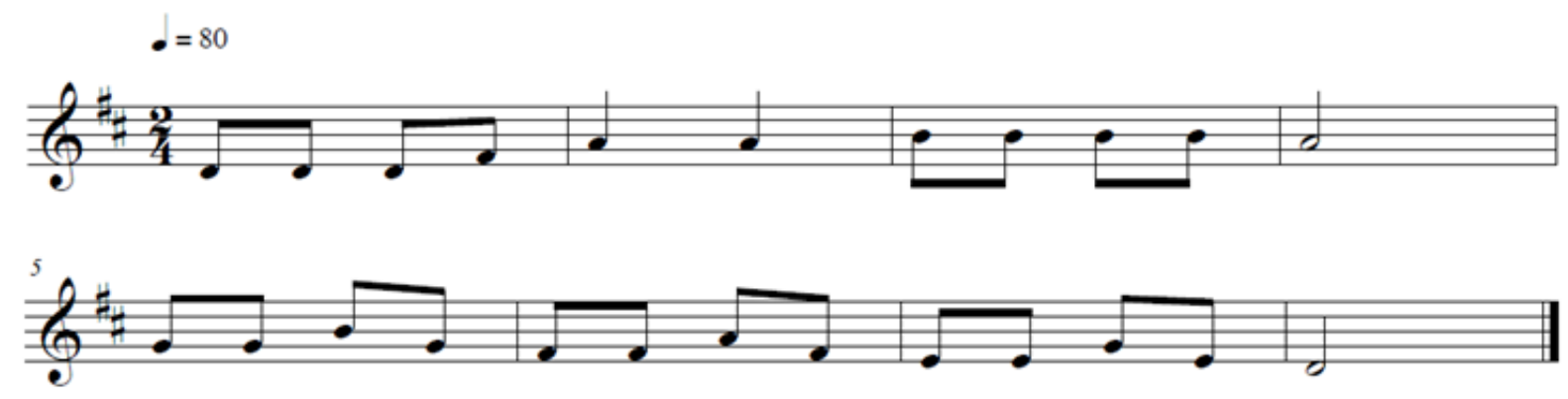

Figure 1. Notes of the song Sağlık (Health)

Adapted from a Czech melody by Erdoğan Okyay, the song 'Sağlık' (Health) is in C major tonality and it is between C4-A4 range in educational music repertoire. In line with the opinions taken from field experts, the song was transposed into D major tonality in form, when considered the importance of students' ability to practice their knowledge on $\mathrm{C}$ major. Harmonic functions of the song, on the other hand, were identified as; $1^{\text {st }}$ measure: I. function; $2^{\text {nd }}$ measure: I. function; $3^{\text {rd }}$ measure: IV. function; $4^{\text {th }}$ measure: I. function; $5^{\text {th }}$ measure: IV. function; $6^{\text {th }}$ measure: I. function; $7^{\text {th }}$ measure: V. function; and $8^{\text {th }}$ measure; I. function. In order to allow students enough time to think and accompany the harmonic functions, the song was arranged in $80 \mathrm{bpm}$, which is an andante tempo. 
- Cici Köpeğim (My Sweet Dog) - Lyrics: Ahmet Muhtar Ataman, Music: French Melody
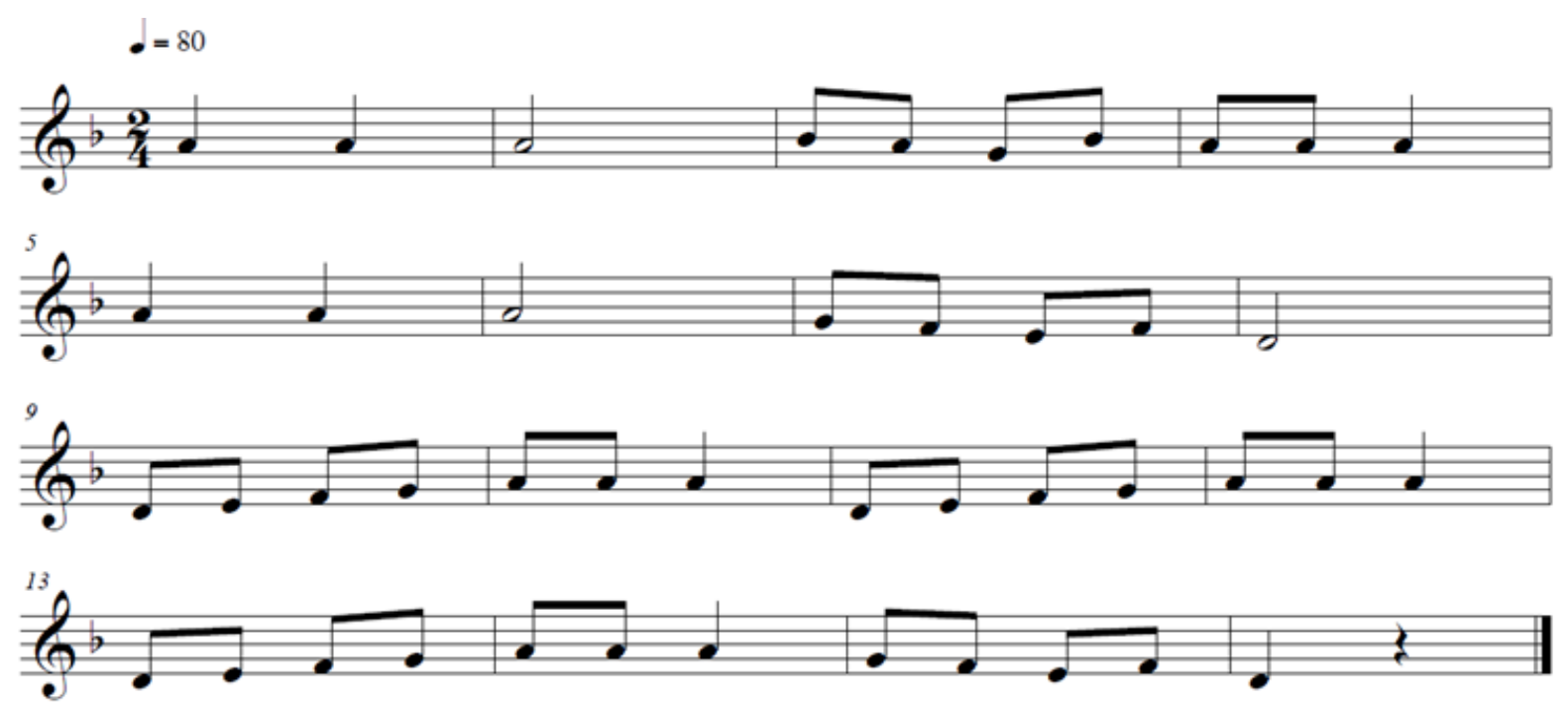

Figure 2. Notes for the song Cici Köpeğim (My Sweet Dog)

The song 'Cici Köpeğim' (My Sweet Dog) is composed of the lyrics written by Ataman on a French melody, is in $\mathrm{D}$ minor tonality and between $\mathrm{D} 4-\mathrm{Bb} 4$ range in educational music repertoire. Considering transposition of the major part in the form into D major tonality, tonality of the song was preserved and remained as D minor in form. Functions of the song were determined as: $1^{\text {st }}$ measure: $I$. function; $2^{\text {nd }}$ measure: I. function; $3^{\text {rd }}$ measure: IV. function; $4^{\text {th }}$ measure: I. function; $5^{\text {th }}$ measure: I. function; $6^{\text {th }}$ measure: I. function; $7^{\text {th }}$ measure: V. function; and $8^{\text {th }}$ measure; I. function; $9^{\text {th }}$ measure: I. function; $10^{\text {th }}$ measure: I. or V. function; $11^{\text {th }}$ measure: I. function; $12^{\text {th }}$ measure: I. or V. function; $13^{\text {th }}$ measure: I. function; $14^{\text {th }}$ measure: I. or V. function; $15^{\text {th }}$ measure: V. function; and $8^{\text {th }}$ measure: I. function. In order to allow students enough time to think and accompany the harmonic functions, the song was arrangedin $80 \mathrm{bpm}$, which is an andante tempo.

- Gel Bize Katıl Bize (Come and Join Us) - Music and Lyrics: Muammer Sun

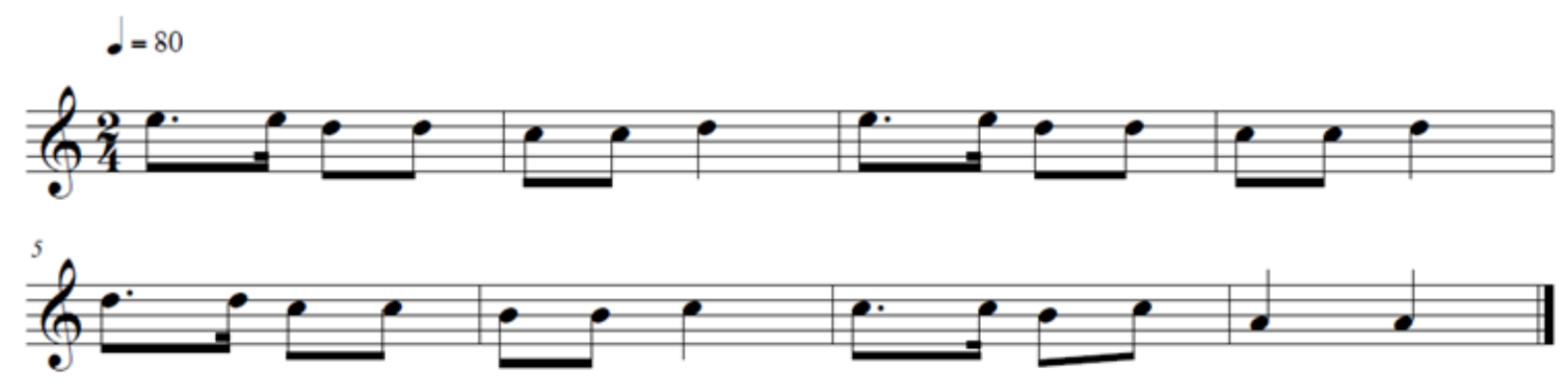

Figure 3. Notes for the song Gel BizeKatılBize (Come and Join Us)

Written and composed by Muammer Sun, the song 'Gel Bize Katıl Bize' (Come and Join Us) is in D huseyni maqam and between D4-A4 range in educational music repertoire. Based on the opinions of specialists, the song was transposed into A, since the huseyni maqam is initially taught in A note. In order to allow students enough time to think and accompany the harmonic functions, the song was arranged in 80 
bpm, which is an andante tempo. In line with the opinions, the harmonic functions of the song were determined as: $1^{\text {st }}$ measure: I. function; $2^{\text {nd }}$ measure: VII. function; $3^{\text {rd }}$ measure: I. function; $4^{\text {th }}$ measure: VII. function; $5^{\text {th }}$ measure: VII. function; $6^{\text {th }}$ measure: III. function; $7^{\text {th }}$ measure: IIIbfunction; and $8^{\text {th }}$ measure: I. function.

Consisting of these three school songs, the form was applied to the $3^{\text {rd }}$ and $4^{\text {th }}$ year undergraduate students studying at Gazi University Gazi Faculty of Education Division of Music Education in September 2019. During the application, the students were given some time to visually analyze the tonality and harmony of the songs. Then, they were asked to accompany these songs fluently with an accompaniment model they want, together with the functions they stated. Application process was recorded on video and shown to 3 field specialists. Arithmetic means of their evaluation results were calculated which led us to the findings of the study.

\section{Findings}

\section{Findings related to the $1^{\text {st }}$ sub-problem}

Table 1. Ability of pre-service music teachers in terms of accompanying the song "Sağllk" (Health)

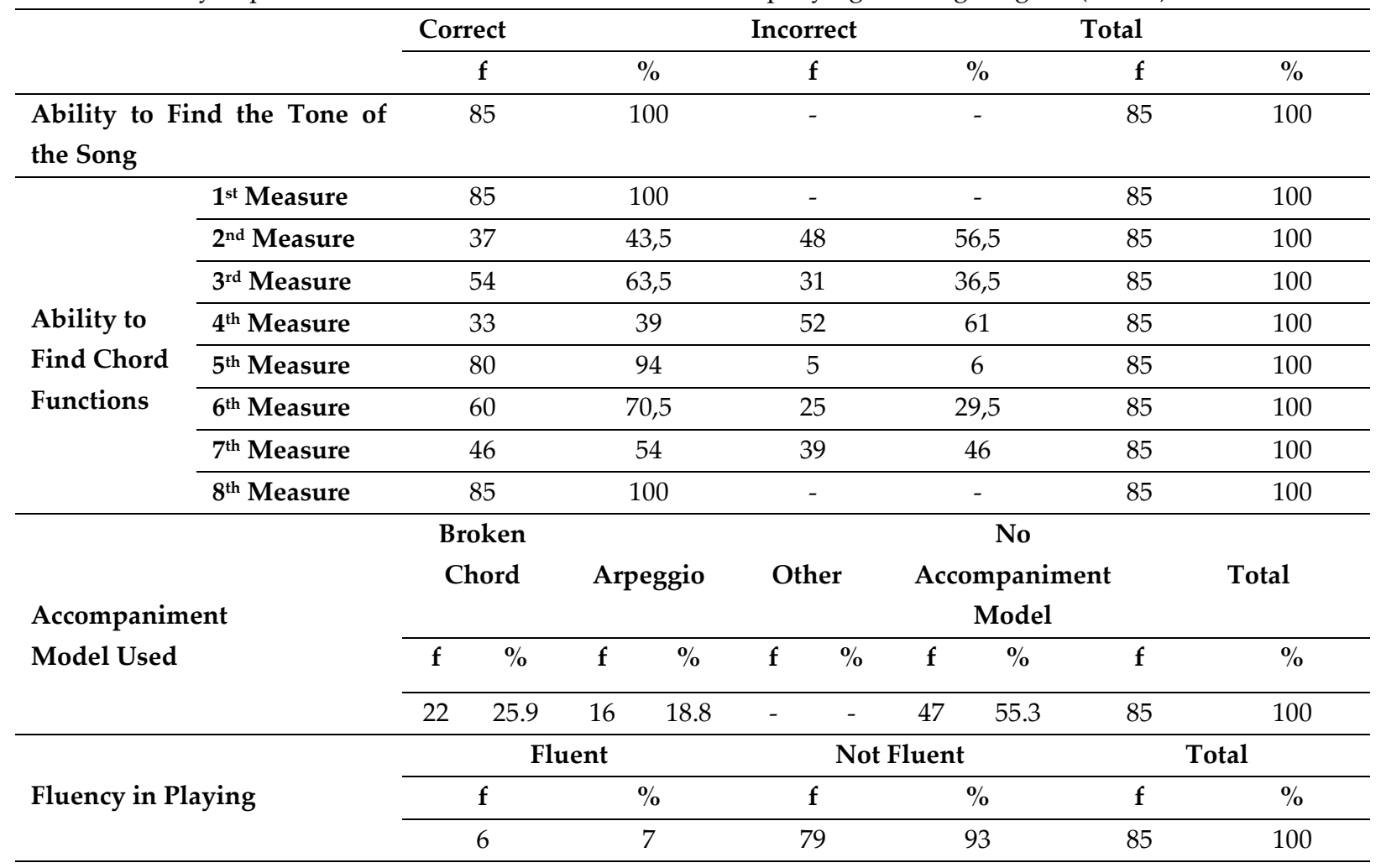

Table 1 demonstrates the pre-service teachers' ability in terms of finding the tone and chord functions of the song Sağllk (Health); its accompaniment based on a model; and playing it fluently. All pre-service music teachers having participated in the study found the correct tone of the song. The success level of pre-service teachers in terms of finding the tonality of the song, which had been transposed into D major, was $100 \%$. When analyzed their ability to find the chord functions, it was revealed that the highest score was in the first and last measure of the song. The participants used D major chord in the beginning and ending of the song, and none of them performed incorrect functioning. On the other hand, although it was supposed to be the I. function chord in $2^{\text {nd }}, 4^{\text {th }}$, and $6^{\text {th }}$ measures, they failed to perform a correct functioning in these measures. When their success level based on measures was analyzed, it was found that they had difficulty in finding the measure mostly in the $2^{\text {nd }}$ and $4^{\text {th }}$ measures. Participants were asked to accompany the chord functions they found with an appropriate accompaniment model, and 47 of them used none. 22 of those who did, preferred broken chord 
and 16 of them performed arpeggio. Being another sub-dimension of the study, analysis of their ability to play fluently revealed that a great majority of the participants had difficulties in doing so. While 6 pre-service teachers were able to perform a fluent accompaniment, the other 79 failed to make smooth function changes between measures and hindered the fluency of the music.

\section{Findings Related to the $2^{\text {nd }}$ Sub-Problem}

Table 2. Ability of pre-service music teachers in terms of accompanying the song "Cici Köpeğim” (My Sweet Dog)

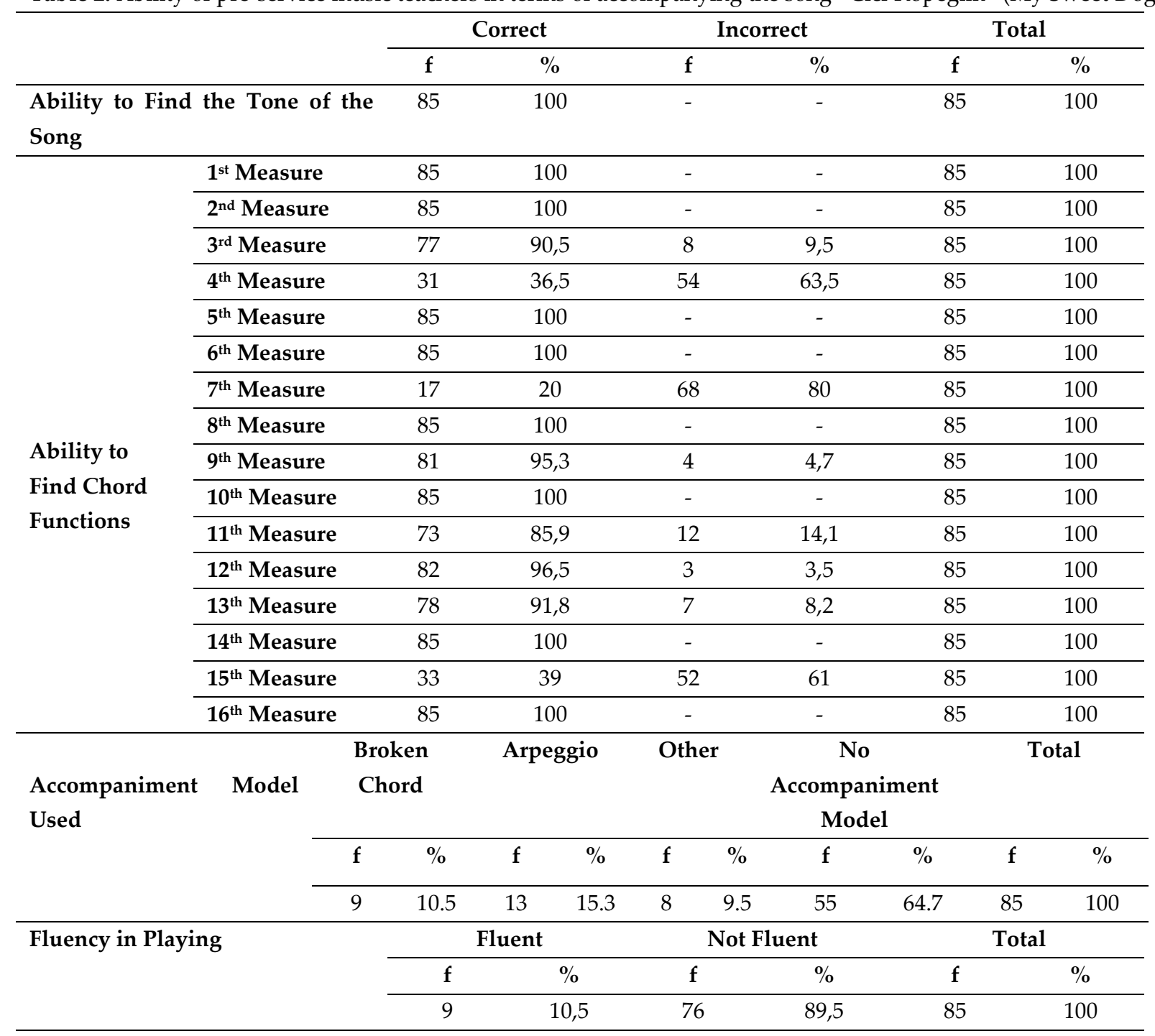

When Table 2 is analyzed, it can be found that the pre-service teachers were able to find the correct tone of the song Cici Köpeğim (My Sweet Dog), which is in D minor. In terms of their ability to find chord functions according to measures, all of the participants were observed to have found the correct function for the $1^{\text {st }}, 2^{\text {nd }}$, $5^{\text {th }}, 6^{\text {th }}, 8^{\text {th }}, 10^{\text {th }}, 14^{\text {th }}$, and $16^{\text {th }}$ measures. The function to be used in all of these measures is the I. function; in other words, D minor chord. The participants' success level was the lowest in $7^{\text {th }}$ and $15^{\text {th }}$ measures, where the $\mathrm{V}$. function should have been used. They did not have difficulties in finding the main function, whereas they could not find the $\mathrm{V}$. function easily. When the accompaniment models were analyzed, 55 pre-service teachers were found to not have used any models; while 9 of them used broken chord, and 13 used arpeggio. 8 participants partially used either of these models or just hit the chord sounds. When their ability to play the piano accompaniments fluently was analyzed, it was found that they were -by a long way- not able to do so. 


\section{Findings Related to the $3^{\text {rd }}$ Sub-Problem}

Table 3. Ability of pre-service music teachers in terms of accompanying the song "Gel BizeKatılBize" (Come and Join Us)

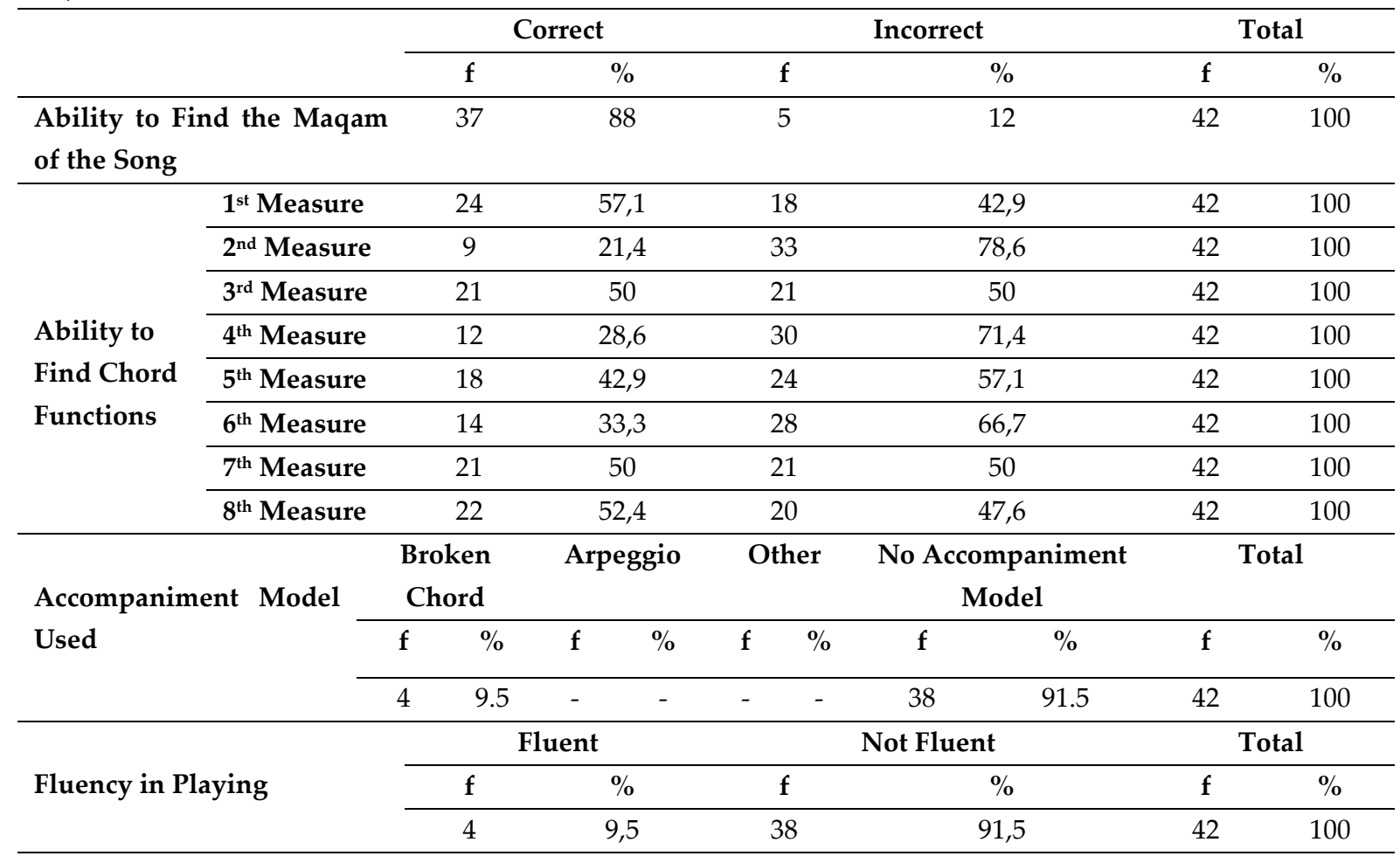

Table 3 demonstrates $4^{\text {th }}$ year undergraduate students' ability in terms of identifying the maqam and chord functions of the song Gel Bize Katıl Bize (Come and Join Us), its accompaniment based on a model, and playing it fluently. $88 \%$ of the 42 pre-service teachers were able to identify the maqam of the song correctly, which is huseyni. The other $12 \%$, on the other hand, were not able to do so or gave a tonal answer. When their ability to identify measure-based chord functions, it was found that the highest score was obtained in the first and eighth measures. Ability of pre-service music teachers, who completed Polyphonization of Turkish Music course, in terms of identifying measure-based chord functions is less than $50 \%$. When they were asked to accompany the song with an appropriate model, only 4 of them performed broken chord, and the rest did not use any models. Although those who played with an accompaniment model showed a fluent performance, this portion is still rather low when the overall number is considered.

\section{Conclusion and Discussion}

The results obtained from the study, purpose of which is to identify pre-service music teachers' ability to accompany school songs with piano, are as follows:

Table 4. Pre-Service Teachers' Ability to Find Tonality/Maqam

\begin{tabular}{lcccccc}
\hline Finding Tonality/Maqam & \multicolumn{2}{c}{ Correct } & \multicolumn{2}{c}{ Incorrect } & \multicolumn{2}{c}{ Total } \\
\cline { 2 - 7 } & $\mathbf{f}$ & $\mathbf{\%}$ & $\mathbf{f}$ & $\mathbf{\%}$ & $\mathbf{f}$ & $\mathbf{\%}$ \\
\hline Sağlık (D Major) & 85 & 100 & - & - & 85 & 100 \\
\hline Cici Köpeğim (D Minor) & 85 & 100 & - & - & 85 & 100 \\
\hline Gel Bize Katıl Bize (A Huseyni) & 37 & 88 & 5 & 12 & 42 & 100 \\
\hline
\end{tabular}


Pre-service teachers were given the notes of one major, one minor, and one maqami song which they were familiar with and asked to find the tone and maqam of these songs. It was found that all of the participants were able to find the tone of the major and minor songs correctly; while a large majority was able to identify the maqam of the huseyni song correctly. Based on this, it can be concluded that the field courses that are provided in undergraduate program and focus on finding the tone and maqam of the song have reached their goals, and provided the necessary knowledge among students.

Table 5. Measure Functioning Status of Pre-Service Teachers

\begin{tabular}{lccc}
\hline Measure Functioning & $\begin{array}{c}\text { Correct Measure } \\
\text { Functioning Average }\end{array}$ & $\begin{array}{c}\text { Incorrect Measure Functioning } \\
\text { Average }\end{array}$ & Total \\
\cline { 2 - 4 } & $\boldsymbol{\%}$ & $\%$ & $\%$ \\
\hline Sağlık & 70,5 & 29,5 & 100 \\
\hline Cici Köpeğim & 90,9 & 9,1 & 100 \\
\hline Gel Bize Katıl Bize & 41,9 & 58,1 & 100 \\
\hline
\end{tabular}

In the second question of the study, pre-service teachers were asked to find the measure-based functions of the tonal and maqami songs. Table 5 demonstrates that participants reached a considerable success level in terms of finding the functions of Cici Köpeğim, which is a minor song. Although it was lower when compared to Cici Köpeğim, it was found that the participants still obtained an above-the-average success in the song Sağlık. In the song Gel Bize Katıl Bize, on the other hand, they were only able to reach a success level of $41.9 \%$. Such an average is rather low for pre-service teachers who are at the end of their undergraduate education and completed all of the field courses. The reason for such an average is thought to have caused from the facts that Polyphonization of Turkish Music is only offered at the $3^{\text {rd }}$ year of the undergraduate program, lasts only for one semester, and that it is offered following the piano accompaniment course. This is a rather short period for students to fully comprehend the chord system with four notes, find appropriate functions for the given melody, and to manage it on the piano with an accompaniment model. The fact that pre-service teachers take maqami analysis and accompaniment courses only for one semester -and right after the tonal accompaniment skills where they are unable to practice adequately- has a negative effect on their efficacy in terms of accompaniment. Piji (2014, p.211) analyzed the scope of the accompaniment course based on the opinions of pre-service music teachers and concluded that such courses are not sufficient to practice the knowledge they learn in theoretical courses. The research conducted by Piji is in support of this study, in terms of its results.

Table 6. Pre-Service Teachers' Status of Using an Accompaniment Model

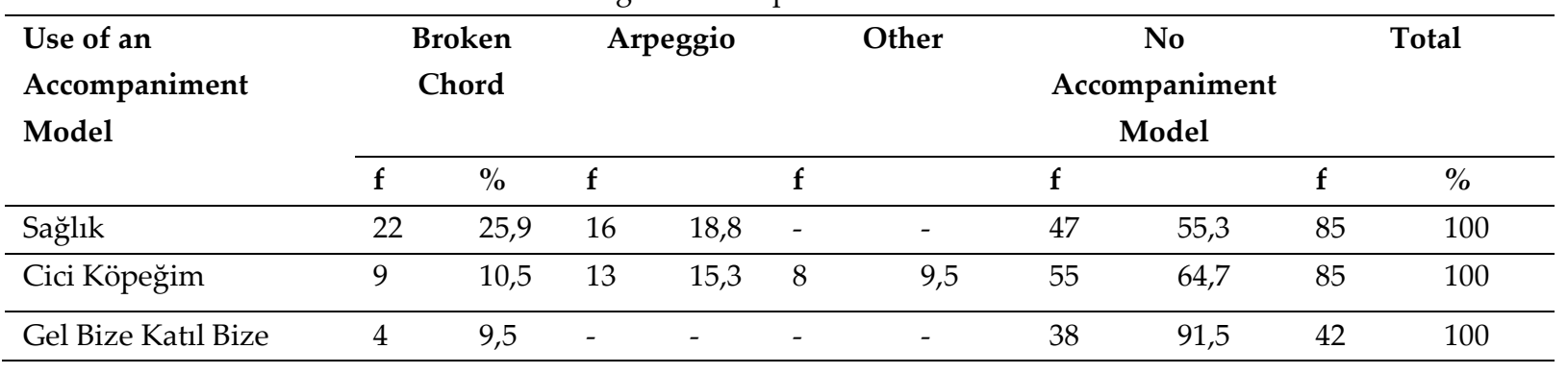

In the study, pre-service teachers were asked to accompany the songs on piano by means of using an appropriate model and the chords they found upon the analysis of the song. It was found that a large majority did not use any model. Broken chord was found to be the common and statistically highest accompaniment model they used in all of the three songs. Arpeggio, on the other hand, was used in the songs Sağlık and Cici 
Köpeğim. Only broken chord was used in the song Gel Bize Katıl Bize. It is rather difficult to create music based on an accompaniment model, while the participants are unable to obtain a high score in identifying the measure-based functions of a monophonic school song. Offering the accompaniment course only for one semester is not enough for students to practice their knowledge on harmony and does not give them the opportunity to fully understand the accompaniment models and create one. In the study conducted in the field of piano accompaniment skills at institutions training music teachers, Özdemir (2018, p.129) concluded that the weekly schedule of accompaniment courses and its credit is not adequate in terms of its practice. At the end of his study, he suggested that the course must be conducted individually as there is not enough time for each student to practice. In terms of its results, Özdemir's research show similarities with this study.

Table 7. Pre-Service Teachers' Ability to Play Fluently

\begin{tabular}{lccc}
\hline Fluency in Playing & Fluent & Not Fluent & Total \\
\cline { 2 - 4 } & $\boldsymbol{\%}$ & $\boldsymbol{\%}$ & $\boldsymbol{\%}$ \\
\hline Sağlık & 7 & 93 & 100 \\
\hline CiciKöpeğim & 10,5 & 89,5 & 100 \\
\hline Gel BizeKatılBize & 9,5 & 91,5 & 100 \\
\hline
\end{tabular}

Performing a fluent music is of great importance not only on piano but in all fields of music. A musical sentence expressed in a musical language will not make any sense if it lacks fluency. With this in mind, ability to play fluently is one of the main criteria particularly while performing collective music. The study concluded that a large majority of pre-service teachers are not able to play fluently. Students face difficulties in putting their theoretical knowledge into practice and to turn their knowledge into behavior, due to the lack of practical courses in their curriculum. In his study where the problems encountered in piano education were analyzed based on the opinions of piano teachers, Yazıc1 (2013, p.147) concluded that $83.3 \%$ of the pre-service music teachers fail to play the piano fluently. In another study focusing on the problems observed in training of music teachers, Jelen (2013, p.274) interviewed academics specialized in the field of piano and concluded that undergraduate piano program must be revised in a way that it involves abilities such as writing accompaniments, accompanying school songs and marches, and improvised accompaniment. Both Yazıcı's and Jelen's studies are in parallel with this research, in terms of their results.

\section{Suggestions}

- The 2018 curriculum, which was developed by the Higher Education Council to be implemented within divisions of music education as the common program, is in effect for 2 years. Therefore, $3^{\text {rd }}$ and $4^{\text {th }}$ year students who participated in this study are subject to the 2014 curriculum. Deficiencies and the order of relevant courses in 2014 curriculum were not amended nor improved in 2018 curriculum. Therefore, the issues asserted in the results of this study are believed to remain in the current curriculum, too. Deficiencies existing in the current program may be completed and sorted out by opening elective courses, which is a freedom given to the universities by Higher Education Council.

- The first two years of music education undergraduate program rather focus on the main knowledge in the field of music. $3^{\text {rd }}$ and $4^{\text {th }}$ years, on the other hand, are composed of courses that the acquired knowledge is put into practice and students are prepared for teaching profession. Accompaniment course is given in the $3^{\text {rd }}$ year, which cause the students to forget its content until they start practicing the profession. That is why, it is believed that scheduling the accompaniment and Polyphonization of Turkish Music courses in the final semester will be more beneficial. 
- Scheduling both the theory and practice of Polyphonization of Turkish Music course within one semester hinders the students' ability to comprehend the theory and put it into practice. In order to digest such a course that is rich in content, the theory and practice must be taught in separate semesters, in a minimum of two.

- The courses such as harmony counterpoint and accompaniment are generally taught in theory at the divisions of music education. Such courses must not stay in theory. Instead, students must play the I-IV-V-I perfect cadence and form a basis to accompany school songs.

- Organization of in-service trainings for music teachers who did not take accompaniment course throughout their undergraduate education or think that it was inadequate, is thought to keep teachers' knowledge on accompaniment updated. 


\section{REFERENCES}

Akbulut, E. (2006). Günümüz müzik eğitimcisi nasıl olmalıdır? Pamukkale Üniversitesi Ĕ̆itim Fakültesi Dergisi, 20(20), 23-28.

Babacan, D. (2009). Müzik eğitimi anabilim dallarında piyanoda eşlik dersi sürecinde caz armonisinin kullanılabilirliğinin değerlendirilmesi. Doktora Tezi. Selçuk Üniversitesi, Sosyal Bilimler Enstitüsü, Konya.

Batıbay, D., Aydınoğlu, O. (2006). Müzik öğretmenliği lisans programında yer alan "eşlik (korepetisyon)" dersinin öğrenci ve öğretmen görüşleri doğrultusunda değerlendirilmesi. Marmara Üniversitesi Atatürk Ĕ̆itim Fakültesi Ĕ̆itim Bilimleri Dergisi, Sayı: 24, 1-26.

Bilen, S. (1995). İşbirlikli öğrenmenin müzik öğretimi ve güdüsel süreçler üzerindeki etkileri. Doktora Tezi. Dokuz Eylül Üniversitesi, Sosyal Bilimler Enstitüsü, İzmir.

Bilgin, S. (1998). Ilköğretim okullarının 2. Kademesinde müzik eğitiminde kullanılan şarkıların Gazi üniversitesi Gazi Eğitim Fakültesi Müzik Eğitimi Bölümü çıkışlı müzik öğretmenleri tarafından piyano ile eşliklenmesi. Doktora Tezi. Gazi Üniversitesi, Fen Bilimleri Enstitüsü, Ankara.

Bilgin, S. (2004). Eğitim müziğinde prozodi. 1924 - 2004 Musiki Muallim Mektebinden günümüze müzik öğretmeni yetiştirme sempozyumu bildiri kitabı. Isparta: Süleyman Demirel Üniversitesi Yayınevi.

Bilgin, S., Şaktanlı, C. (2007). Okul şarkılarının müzik öğretmeni tarafından piyano ile eşliklenmesi. Dokuz Eylül Üniversitesi Buca Ĕ̆itim Fakültesi Dergisi, Sayı: 21, 130-133.

Çevik, B. D., Güven, E. (2011). İlköğretim müzik öğretmenlerinin okul şarkılarına piyanoda eşlik yapabilme konusuna ilişkin görüşleri üzerine bir çalışma. Balıkesir Üniversitesi Sosyal Bilimler Enstitüsü Dergisi, 14(25), 86-98.

Dağdeviren, M. (2006). Müzik öğretmeni yetiştiren kurumlarda piyanoda eşlik öğretimi. Ulusal müzik eğitimi sempozyumu bildirisi. Denizli: Pamukkale Üniversitesi Eğitim Fakültesi.

Demirtaş, S. (2011). Illköğretim 7. sını müzik dersinde şarkıların piyano ile eşlikli öğretilmesinin öğrenci kazanımlarına etkileri. Yüksek Lisans Tezi, Pamukkale Üniversitesi, Sosyal Bilimler Enstitüsü, Denizli.

Gün, E., Demirtaş, O. (2016). Müzik öğretmeni adaylarının piyano eserlerindeki armonik yapıyı analiz etme becerileri. İdil Dergisi, 5(25), 1387-1399.

Gün, E., Öztürk T. (2017). Piyanoda deşifrenin önemi, tekniği ve geliştirilmesi. Pamukkale Üniversitesi Sosyal Bilimler Enstitüsü Dergisi, Sayı: 31, 121-128.

Jelen, B. (2013). Türkiye'de müzik öğretmeni yetiştirme sürecinde piyano eğitiminde karşılaşılan sorunlar. Rast Müzikoloji Dergisi, 1(1), 258-285.

Karakaya, İ. (2012). Bilimsel araştırma yöntemleri - bölüm III (57-83). Ed: Abdurrahman Tanrı̈ğen. 3. Baskı. Ankara: Anı Yayıncilık

Küçükayvaz, İ., E. (2019). Çocuk korolarının sahne performanlarında piyano eşliklerinin kullanım durumları. Afyon Kocatepe Üniversitesi Akademik Müzik Araştırmaları Dergisi, 5(9), 65-90.

Lavignac, A. (1939). Musiki terbiyesi. Çeviren: Abdülmalik Denker. İstanbul: Kanaat Kitabevi.

Özalp, U., Özdemir, G. (2015). Deşifre eşlik çalımında akor şifrelerinin kullanımı. Pamukkale Üniversitesi Sosyal Bilimler Enstitüsü Dergisi, Sayı: 22, 47-53.

Özdemir, G. (2018). Müzik öğretmeni yetiştiren kurumlarda piyano ile eşlikleme becerileri üzerine sistematik bir derleme çalışması. Pamukkale Üniversitesi Sosyal Bilimler Enstitüsü Dergisi, Sayı: 30, 121-132. 
Özmenteş, S. (2005). Müzik eğitiminin boyutları ve çalgı eğitimi. İnönü Üniversitesi Eğitim Fakültesi Dergisi, 6(9), 89-98.

Pala, A., Zahal, O., Gürpınar, E. (2016). Müzik öğretmenlerinin ortaokul müzik derslerinde piyano - org çalgılarını kullanabilme durumları. 2. Uluslararası Müzik ve Dans Kongresi Bildiri Kitabı, 10-22.

Piji, D. (2007). Müzik öğetmeni adaylarına yönelik piyano ile eşlik alanında yeterlik algısı ölçeğinin geliştirilmesi. Marmara Üniversitesi Eğitim Bilimleri Dergisi, 26(1), 111-132.

Piji, D. (2014). Müzik öğretmeni adaylarının bakışı ile eşlik çalma dersinin değerlendirilmesi. Hacettepe Üniversitesi Ĕ̆itim Fakültesi Dergisi, 29(2), 198-214.

Piji, P. (2018). Piyano eşliğinin eğitim müziğindeki önemi ve müzik öğretmenlerine yönelik piyano eşlik yöntemleri. Yüksek Lisans Tezi. Haliç Üniversitesi, Sosyal Bilimler Enstitüsü, İstanbul.

Say, A. (2005). Müzik sözlüğ̈̈. 2. Baskı. Ankara: Müzik Ansiklopedisi Yayınları.

Sevgi, A. (2005). Müzik öğretmenliği mesleği gerekleri doğrultusunda bir armoni eğitimi. Gazi Üniversitesi Gazi Ĕ̆itim Fakültesi Dergisi, 25(1), 199-211.

Sökmen, K., T. (2018). Türkiye'de müzik öğretmenlerinin piyanoda eşlik sorunları ve çözümleri üzerine bir çalışma. Eurosian Journal of Music And Dance, Sayı: 13, 23-33.

Sönmezöz, F. (2006a). Müzik öğretmeni yetiştiren kurumlarda öğrenim gören lisans öğrencilerinin eşlik dersine ilişkin görüşlerinin belirlenmesi. Ulusal Müzik Eğitimi Sempozyumu Bildirisi. Denizli: $\quad$ Pamukkale Üniversitesi Eğitim Fakültesi.

Sönmezöz, F. (2006b). Müzik öğretmeni yetiştiren kurumlardaki eşlik öğretiminin müzik öğretmenlerinin görüşleri doğrultusunda değerlendirilmesi. Doktora Tezi, Gazi Üniversitesi, Eğitim Bilimleri Enstitüsü, Ankara.

Şaktanlı, C., Özelma, Y. (2014). Eğitim müziği çokseslendirme yaklaşımları ve yaklaşımların ilköğretim müzik dersi kapsamında kullanımı ile ilgili örnek uygulamalar. İnönü Üniversitesi Sanat ve Tasarım Dergisi, 4(9), 43-58.

Tecimer, B. (2005). İşlevsel piyano becerilerinin müzik öğretmenleri için önemi. Gazi Üniversitesi Gazi Ĕ̆itim Fakültesi Dergisi, 25(1), 149-154.

Türkmen, F. (2010). Türk çocuk şarkıları dağarcığının müzik öğretmenlerinin yaklaşımları açısından değerlendirilmesi. Afyon Kocatepe Üniversitesi Sosyal Bilimler Dergisi, 12(2), 183-202.

Yazıcı, T. (2013). Piyano öğretiminde karşılaşılan sorunların piyano öğretmenleri tarafından değerlendirilmesi. Sanat Eğitim Dergisi, 1(2), 130-150.

Zuckmayer, E., Cangal, N., Atalay, A. (1976). 1. sınıf müzik teorisi (armoni ve kontrpuan). Yaykur Açı Yüksek Öğretim Dairesi Eğitim Enstitüleri Müzik Bölümü, Ankara. 